\title{
STUDY OF PHYSIOLOGICAL PROCESSES IN CORN GRAIN DURING STORAGE UNDER HERMETIC CONDITIONS
}

\begin{abstract}
In recent decades, in addition to the traditional grain storage in dry conditions, the technology of grain storage without access of air - in hermetic conditions has gained a widespread in polymeric grain bags (silobags). The aim of the research was to study the regularities of the physiological processes of respiration in maize grain when stored in hermetic conditions, which would determine the terms of safe storage of different humidity grain in polymeric grain bags and reduce the costs of its processing and storage. The object of research is the technology and processes of freshly harvested corn grainstorage. As the main subject of the study, a dent-type hybrid of corn DKS 3705 was used, which, according to its botanical and agronomic properties, was better for use on food and non-food needs and for export.

On the basis of the conducted researches it was established that with an increase in initial moisture of grain from $14 \%$ to $21 \%$ and subsequent storage in hermetic conditions at constant temperatures the natural losses of dry matter of grain increase in comparison with losses of dry matter of grain with standardhumidity (14\%), in particular, at a temperature of $18{ }^{\circ} \mathrm{C}$ by $112 \%$, at a temperature of $11{ }^{\circ} \mathrm{C}$ by $296 \%$ and at a temperature of $4{ }^{\circ} \mathrm{C}$ by $123 \%$. Thus, it is shown that the decrease of the temperature regimes of grain storage of maize with different initial humidity under hermetic conditions contributes to the reduction of the intensity of the natural physiological processes in it and, consequently, the natural losses of its dry matter.

It has been established that during storage of corn grain for three months and reduction of temperature storage conditions from $18{ }^{\circ} \mathrm{C}$ to $11{ }^{\circ} \mathrm{C}$ in samples of grain with an initial humidity of $14 \%$ decrease: the absorption rate of oxygen by $34 \%$, carbon dioxide emissions, loss of dry matter and the production of thermal energy by $66 \%$. For a grain with an initial humidity of $21 \%$, the reduction in intensity under the same conditions is: for absorption of oxygen $22 \%$, the production of carbon dioxide $28 \%$, losses of dry matter $37 \%$ and the production of thermal energy $23 \%$.

Reducing the storage temperatures of corn from $11^{\circ} \mathrm{C}$ to $4^{\circ} \mathrm{C}$ in samples of grain with an initial humidity of $14 \%$ reduces the intensity: absorption of oxygen by $79 \%$, carbon dioxide generation by $60 \%$, dry matter loss by $60 \%$, and the generation of thermal energy by $60 \%$. For grain with an initial moisture content of $21 \%$ under the same conditions, the intensity decreases: oxygen absorption by $28 \%$, carbon dioxide generation by $77 \%$, dry matter loss by $77 \%$, and heat generation by $77 \%$. Established regularities of the physiological processes in corn grain with different initial humidity when stored in hermetic conditions at different temperatures, it is possible to predict the characteristics of gas exchange processes in the grain mass, natural losses of dry matter and the generation of heat during storage of grain.
\end{abstract} dry matter.

Key words: corn grain, silobags, hermetic storage conditions, oxygen absorption, carbon dioxide, heat generation, loss of

\section{Formulation of the problem.}

Respiration is an important physiological process that underlies the metabolism of living organisms. The intensity of respiration is an indicator of the biological activity of the stored grain mass. The study of the intensity of breathing of grain is directly related to the theory and practice of storage. This is due to the determination of the losses of dry matter of grain during storage, as well as the determination of environmental conditions that characterize the optimal storage conditions.

Substances that take part in the process of respiration of cereals include carbohydrates of grain and oxygen from atmospheric air, to the final products carbon dioxide, water and alcohol. In the process of respiration, the cells of the grain use energy through the decoupling of their organic substances. Thus, the respiration of grain during storage is accompanied by the loss of dry matter, which is called natural loss. Depending on the conditions in which the grain is located, the respiration process can run in three directions (types): aerobic (with oxygen), anaerobic (no oxygen) or mixed [1].

Loss of grain dry matter duringrespirationis not restored, and it is attributed to the inevitable costs. The question of the amount of respiration losses is

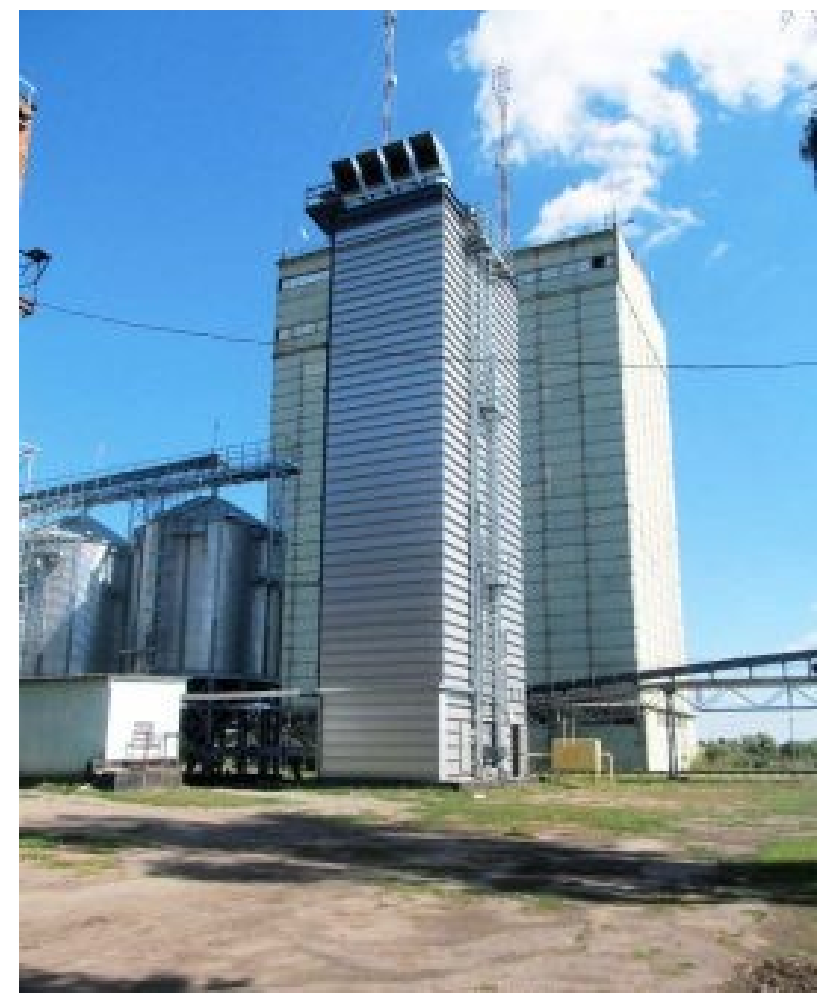


particularly important because these grain losses during storage can increase, depending on the condition of the grain and the conditions of its storage (humidity, temperature, aeration, etc.). In analyzing this process, it is necessary to take into account not only the complex set of biochemical transformations in the grain, which are caused by their intensity, but also the type of respiration. The intensity of the process of grain respiration, depends on various factors, can be characterized by dry matter loss during storage, heat generation, oxygen absorption and carbon dioxide generation.

In recent decades, in addition to the traditional storage of grain in a dry condition, the technology of its storage without access to air - in hermetic conditions has gained a widespread in polymeric grain bags (silobags). It is used by such traditional producers and exporters of grain as Argentina, USA, Canada, and others. This technology is also becoming widespread in Ukraine, and some enterprises already have their own experience of grain storage in such hermetic polymer bags, especially corn. However, in the literature there is not enough theoretical and experimental data of the study of the regularities of physiological processes occurring in grain masses, in particular, the processes of respiration of grain under hermetic conditions. This determined the purpose of this work

The aim of the research was to study the regularities of the physiological processes of respiration in maize grain when stored in hermetic conditions, which would determine the terms of safe storage of maize grainof different humidity in polymeric grain bags and reduce the costs of its processing and storage.

The object of research is the technology and processes of freshly harvested corn grain storage. As the main subject of the study, a dent-type hybrid of corn DKS 3705 was used, which according to our previous studies [2], according to its botanical and agrotechnical properties [3], was better for use on food and non-food needs and for export.

\section{Research methodology.}

For experimental studies of the intensity of grain respiration a test bench was developedat the Department of Grain Storage Technology in ONAFT on the basis of a multicomponent individual signaling device-gas analyzer DOSOR-S-M, manufactured at the Scientific and Production Enterprise ORION (Kharkiv), which allows highly accurately determine the concentration of carbon dioxide and oxygen in multicomponent gas mixtures and air [4]. A detailed description of the test bench, signaling device-gas analyzer DOSOR-S-M and methods of studying the intensity of respiration of the grain are given in publications [5].

Based on the purpose of the research to conduct experiments on the study of the intensity of the different humidity corn grain respiration processes, which was stored in hermetic conditions at different temperatures, two samples of grain with an average humidity of 14 and $21 \%$ were selected for storage at temperatures of 4,11 and $18^{\circ} \mathrm{C}$ (6 samples of grain). The selected grain moisture content of about $21 \%$ is the most characteristic of the period of corn harvesting and allows to practically realize the technology of its storage in sealed polymeric grain bags. With higher values of the moisture content of corn, its safe storage can be problematic. The temperature range of $4 \ldots 18^{\circ} \mathrm{C}$ is close to the conditions of the autumn-winter period of cornharvesting.

In each of the 6 tanks with the grain, with the help of a gas analyzer, Dosoz-S-M the initial values of the oxygen content and carbon dioxidewere determined. Subsequently, containers with test samples with humidity of 14,21 and $28 \%$ were placed for storage in 3 capacities, which maintained the temperatures 4,11 and $18^{\circ} \mathrm{C}$. The parameters of the gas environment were determined weekly throughout the period of storage of grain samples in grain containers. At the same time, all operations of connection and disconnection of the gas analyzer from the containers of the grain were performed in such a way as to prevent the external air from entering them. The total storage time of grain samples was 3 months.

\section{Research results.}

According to the results of experiments, for all 6 grain samples stored in hermetic conditions at different temperatures, numerical values of the mass of absorbed oxygen and produced carbon dioxide were obtained, on the basis of which the losses of graindry matter and heat energy generationwere calculated. Based on the data obtained, the corresponding kinetic curves were constructed, which give a clear idea of the nature of the patterns of grain respiration physiology and related processes, as well as reveal trends in the influence of selected experimental conditions for storing grain of different humidity on the intensity of physiological processes at different temperaturesimitating grain storage conditions in the autumn-winter period.

Fig. 1 shows the kinetics of oxygen absorbtion and carbon dioxide generationof maize grain with an initial moisture content of $21 \%$ when stored in hermetic conditions at a temperature of $11^{\circ} \mathrm{C}$, which are most typical in terms of the moisture content and storage temperature. It is clear from the graphs that during the first four weeks of the experiment, the nature of the absorption of $\mathrm{O}_{2}$ and the release of $\mathrm{CO}_{2}$ practically does not change, and there is also a tendency for more intensive carbon dioxide generation than oxygen

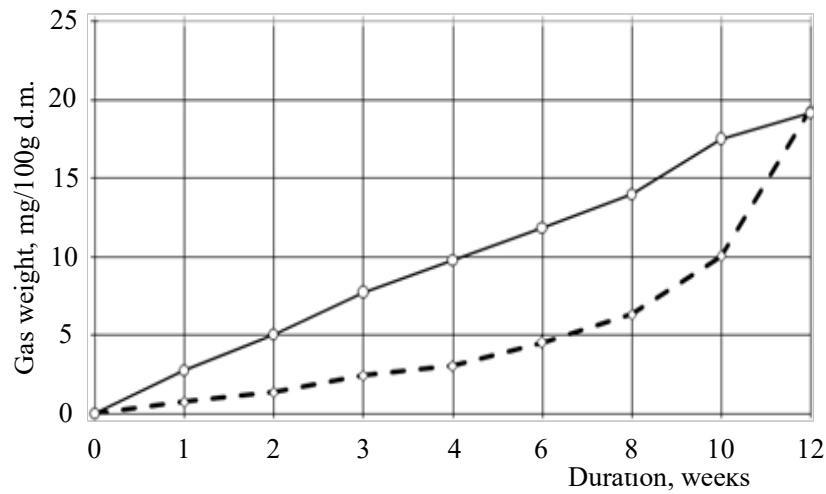

—carbon dioxide- - - -oxygen

Fig. 1 - Kinetics of corn grainoxygen absorption processesand the production of carbon dioxide with an initial moisture content of $21 \%$ during storage under anaerobic conditions at a temperature of $11^{\circ} \mathrm{C}$ 
absorption.

Analysis of kinetic graphs for other grain parameters and storage conditions showed that the characteristic difference in the flow of these processes in grain with different initial humidity is that in samples with a humidity above the conditioned (14\%), they proceed more intensively. As a result, in the first four weeks of the experiment, the average values of absorbed oxygen and produced carbon dioxide in sample with an initial moisture content of $21 \%$ exceed the corresponding processes in the sample with a humidity of $14 \%, 166 \%$ by the amount of oxygen absorbed and by $191 \%$ by generated carbon dioxide.

Fig. 2 shows the kinetics of losses of dry matter and the heat energy generation of corn grain with an initial moisture content of $21 \%$ when stored in airtight conditions at a temperature of $11^{\circ} \mathrm{C}$. From these data, it is evident that the trends in the change of the dry matter loss and the generated heat energy during the first four weeks of the experiment in samples of grain with an initial moisture content of $21 \%$ also exceed those of the grain with an initial moisture of $14 \%$ by $191 \%$.

After the fourth week of storage in samples of grain with different initial humidity, stored at a temperature of $11^{\circ} \mathrm{C}$, there are also some changes in the nature and intensity of the processes of respiration. So, during the next six weeks of storage (from the 4th to the 10 th week), as well as in conditioned humidity sample $(14 \%)$, the process of aerobic respiration is accompanied by a more pronounced absorption of oxygen than the generation of carbon dioxide. At the same time, the intensity of these processes in grain with a moisture content of $21 \%$ exceeds the intensity of absorption of oxygen by $5 \%$ and exceeds the intensity of carbon dioxide generation by $206 \%$ compared to the sample with humidity of $14 \%$.Starting from the 10 th week of grain storage with an initial moisture content of $21 \%$, the type of grain respirationhas changedfrom purely aerobic to mixed, which is expressed in the change in the ratio of the amount of absorbed oxygen to the generated carbon dioxide. This feature is associated with a decrease in the oxygen content of the test sample gas environment - from $19.63 \%$ at the beginning of the experiment, to $1.72 \%$ from the 10th week of the study. At the same time, the

\section{Fig. 2 - Kinetics of corn graindry metterloss and the generation of heat energy with an initial moisture content of $21 \%$ when stored in anaerobic conditions at a temperature of $11^{\circ} \mathrm{C}$}

intensity of the process of absorption of oxygen and the generation of carbon dioxide from grain with an initial moisture content of $21 \%$ is higher than the corresponding parameters of the sample with air humidity and exceeds them by $3.3 \%$ and $459 \%$ respectively.

In addition, according to the change in the type of respiration, the kinetics of dry matter losses and heat energy is also changing - in the sample of grain with an initial moisture content of $21 \%$ of dry matter loss, and the amount of heat energy during storage over the last two weeks exceeds similar indicators of grain with consitioned humidity, respectively by $490 \%$ and $442 \%$.

Summary of the results of the study of physiological processes in corn grainwhen stored in sealed conditions for 3 months are given in Table1.

Table 1 shows that the reduction of temperature regimes for the storage of maize grain with different initial humidity under hermetic conditions contributes to the reduction of the intensity of the natural physiological processes in it and, consequently, the natural losses of its dry matter.

\section{Conclusions}

On the basis of the conducted researches it was established that with an increase in initial moisture of grain from $14 \%$ to $21 \%$ and subsequent storage in hermetic conditions at constant temperatures the natural

Table 1 - Results of the study of physiological processes in corn grain when stored in airtight conditions for 3 months

\begin{tabular}{|c|c|c|c|c|c|c|}
\hline \multicolumn{2}{|c|}{ Storage conditions } & \multirow[t]{2}{*}{ Respiration type } & \multicolumn{2}{|c|}{ Gas exchange, mg / 100 g d.m. } & \multirow{2}{*}{$\begin{array}{l}\text { Loss of dry } \\
\text { matter, mg } \\
/ 100 \mathrm{~g} \\
\text { d.m. }\end{array}$} & \multirow{2}{*}{$\begin{array}{l}\text { Heat } \\
\text { production, } \\
\mathrm{kJ} / 100 \mathrm{~g} \\
\text { d.m. }\end{array}$} \\
\hline $\begin{array}{c}\text { the initial } \\
\text { grain } \\
\text { humidity, \% }\end{array}$ & $\begin{array}{c}\text { storage } \\
\text { temperature }\end{array}$ & & $\begin{array}{l}\text { absorption } \\
\text { of oxygen }\end{array}$ & $\begin{array}{l}\text { carbon dioxide } \\
\text { production }\end{array}$ & & \\
\hline \multirow{3}{*}{14} & 4 & aerobic & 2,57 & 2,01 & $\begin{array}{r}1,37 \\
\end{array}$ & 946 \\
\hline & 11 & aerobic & 12,42 & 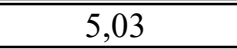 & 3,43 & 2364 \\
\hline & 18 & aerobic and mixed & 18,74 & 14,98 & 10,22 & 7045 \\
\hline \multirow{3}{*}{21} & 4 & aerobic & 13,74 & 4,49 & 3,06 & 2110 \\
\hline & 11 & aerobic and mixed & 19,13 & 19,39 & 13,57 & 9011 \\
\hline & 18 & aerobic and mixed & 24,64 & 26,90 & 21,68 & 11648 \\
\hline
\end{tabular}


losses of dry matter of grain increase in comparison with losses of dry matter of grain with conditioned humidity (14\%), in particular, at a temperature of $18{ }^{\circ} \mathrm{C}$ by $112 \%$, at a temperature of $11^{\circ} \mathrm{C}$ by $296 \%$ and at a temperature of $4{ }^{\circ} \mathrm{C}$ by $123 \%$.

It has been established that during storage of corn grain for three months and reduction of temperature storage conditions from $18{ }^{\circ} \mathrm{C}$ to $11{ }^{\circ} \mathrm{C}$ in samples of grain with an initial humidity of $14 \%$ decrease: the absorption rate of oxygen by $34 \%$, carbon dioxide emissions, loss of solids and the allocation of thermal energy on $66 \%$. For a grain with an initial humidity of $21 \%$, the reduction in intensity under the same conditions is: for absorption of oxygen $22 \%$, the allocation of carbon dioxide $28 \%$, losses of solids $37 \%$ and the allocation of thermal energy $23 \%$.
Reducing the storage temperatures of corn from $11^{\circ} \mathrm{C}$ to $4{ }^{\circ} \mathrm{C}$ in samples of grain with an initial humidity of $14 \%$ reduces the intensity: absorption of oxygen by $79 \%$, carbon dioxide emissions by $60 \%$, dry matter loss by $60 \%$, and the generation of thermal energy by $60 \%$. For grain with an initial moisture content of $21 \%$ under the same conditions, the intensity decreases: oxygen uptake by $28 \%$, carbon dioxide emissions by $77 \%$, dry matter loss by $77 \%$, and heat generation by $77 \%$.

Thus, the established regularities of the physiological processes in corn grain with different initial humidity when stored in airtight conditions at different temperatures allow us to predict the characteristics of gas exchange processes in the grain mass, natural losses of dry matter and the allocation of heat in the storage of grain.

\section{REFERENCES}

1. Trisvyatsky, L.A. Storage of grain: ed. 4th remake and additional [text] / L.A. Triswiatsky - M .: Kolos, 1975. - 400 p.

2. Babkov A., Zhelobkova M. Research of agrotechnological characteristics of grain of certain corn hybrids // Scientific. etc. / Odessa. nats acad. food. technologies. Odessa, 2018. Vol. 82, no. 2. P. $106-115$

3. DSTU 4525: 2006 National Standard of Ukraine. Dttp://zernodisp:com ua/userfiles/files/normativnye_dokumenty/dstu-4525-2006-ku 12.11.2018

4. Signaling-analyzers of gases, combustible gases and vapors "DOSOR-C". URL: www.orion.com.ua (application date: 12/11/2018)

5. Stankevich, G. Modern approach to studying the intensity of respiration of grain [Text] / G.N. Stankevich, A.V. Babkov, M.Zh. Kisatova // Vestn. Almati technologist. Un-that. 2014. Issue 2 (103). P. 45-51.

А.В. БАБКОВ, канд. техн. наук, ст. викладач, Одеська начіональна академія харчових технологій, м. Одеса М.В. ЖЕЛОБКОВА, директор ТОВ «МЛИН БАЗА», м. Андрушівка Житомирської обл.

\section{ДОСЛІДЖЕННЯ ФІЗІОЛОГІЧНИХ ПРОЦЕСІВ У ЗЕРНІ КУКУРУДЗИ ПРИ ЗБЕРІГАННІ В ГЕРМЕТИЧНИХ УМОВАХ}

\section{Анотація}

Останніми десятиліттями, окрім традиційного зберігання зерна в сухому стані, велике поширена набрала технологія його зберігання без доступу повітря - в герметичних умовах в полімерних зернових рукавах (мішках). Метою досліджень було вивчення закономірностей фізіологічних процесів дихання у зерні кукурудзи при зберіганні в герметичних умовах, щзо дозволить визначити терміни безпечного зберігання зерна кукурудзи різної вологості в полімерних зернових рукавах та зменшити витрати на його доробку $і$ зберігання. Об'єктом дослідження є технологія та прочеси зберігання свіжозібраного зерна кукурудзи. В якості основного предмету дослідження використовували гібрид зерна кукурудзи зубоподібного типу ДКС 3705, який за своӥми ботанічними і агротехнічними властивостями виявився кращим для використання на продовольчі $і$ непродовольчі потреби та для експортування.

На основі проведених досліджень встановлено, щуо при підвищенні початкової вологості зерна з $14 \%$ до 21\% та подальшому його зберіганні у герметичних умовах за сталих температур збільшуються природні втрати сухих речовин зерна порівняно з втратами сухих речовин зерна з кондииійною вологістю (14\%), зокрема, за температури $18{ }^{\circ} \mathrm{C}$ на $112 \%$, за температури $11{ }^{\circ} \mathrm{C} \mathrm{на} 296 \%$ та за температури $4{ }^{\circ} \mathrm{C} \mathrm{на} 123 \%$. Таким чином показано, щз зниження температурних режимів зберігання зерна кукурудзи з різною початковою вологістю у герметичних умовах сприяє зменшенню інтенсивності перебігу природних фізіологічних процесів в ньому та, відповідно, природних втрат його сухих речовин.

Встановлено, щзо при зберіганні зерна кукурудзи впродовж трьох місяців та зниженні температурних умов зберігання з $18{ }^{\circ} \mathrm{C}$ до $11{ }^{\circ} \mathrm{C}$ у зразках зерна з початковою вологістю $14 \%$ зменшуються: інтенсивність поглинання кисню на $34 \%$, виділення вуглекислого газу, втрати сухих речовин та виділення теплової енергї на $66 \%$. Для зерна з початковою вологістю $21 \%$ зменшення інтенсивності за тих же умов складає: для поглинання кисню $22 \%$, виділення вуглекислого газу $28 \%$, втрат сухих речовин $37 \%$ і виділення теплової енергї $23 \%$.

При зниженні температур зберігання зерна кукурудзи з $11{ }^{\circ} \mathrm{C}$ до $4{ }^{\circ} \mathrm{C}$ у зразках зерна з початковою вологістю $14 \%$ зменшується інтенсивність: поглинання кисню на $79 \%$, виділення вуглекислого газу на $60 \%$, втрати сухих речовин на 60 \% і виділення теплової енергї̈ на $60 \%$. Для зерна з початковою вологістю $21 \%$ за 
тих же умов зменшуються інтенсивність: поглинання кисню на $28 \%$, виділення вуглекислого газу на $77 \%$, втрати сухих речовин на $77 \%$ і виділення теплової енергії на $77 \%$. Встановлені закономірності перебігу фізіологічних прочесів у зерні кукурудзи з різною початковою вологістю при зберіганні в герметичних умовах за різних температур дозволяють прогнозувати характеристики газообмінних процесів у зерновій масі, природні втрати сухих речовин та виділення теплоти при зберіганні зерна.

Ключові слова: зерно кукурудзи, полімерні зернові рукави, герметичні умови зберігання, поглинання кисню, виділення вуглекислого газу, виділення теплоти, втрати сухих речовин.

\title{
ЛІТЕРАТУРА
}

1. Трисвятский, Л.А. Хранение зерна: изд. 4-е перераб. и доп.[Текст]/ Л.А. Трисвятский. - М.: Колос, 1975. - 400 с.

2. Бабков А.В., Желобкова М.В. Дослідження агротехнологічних характеристик зерна окремих гібридів кукурудзи // Наук. пр. / Одес. наи. акад. харч. технологій. Одеса, 2018. T. 82, вип. 2. С. $106-115$.

3. ДСТУ 4525:2006 Національний стандарт Украйни. Кукурудза. Технічні умови. URL: http://zernodisp.com.ua/userfiles/files/normativnye_dokumenty/dstu-4525-2006-kukuruza.pdf (дата звернення 12.11.2018).

4. Сигнализаторы-анализаторы газов, горючих газов и паров «ДОЗОP-C». URL: www.orion.com.ua (дата звернення 12.11.2018).

5. Станкевич, Г.Н. Современный подход к изучению интенсивности дыхания зерна [Текст] / Г.Н. Станкевич, А.В. Бабков, М.Ж. Кизатова // Вестн. Алмат. технолог. ун-та. 2014. Bып. 2(103). C. 45-51.

Надійшла 11.12.2018 р. Рецензія 15.12.2018.

До друку 19.12.2018.

Адреса для переписки:

вул. Канатна, 112, м. Одеса, 65039

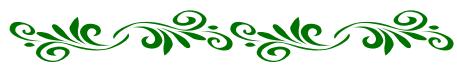

\section{STUDY OF MOISTURE ABSORPTION OF SWEET CORN GRAIN OF DIFFERENT FRACTIONS}

\begin{abstract}
Annotation
In Ukraine, as the raw material for the production of cereals, flour, flakes, the following main crops are used: wheat, barley, buckwheat, oats, corn, rice, millet, peas. The volume of world grain production has grown significantly in recent years. In Ukraine, corn is the main fodder crop, and only a small amount is used as a food. Corn has the leading place among the major grain crops in world agricultural production. Corn grain production is concentrated in warm regions. In some regions, corn is the basis of the traditional nutrition of the population, but basically it forms part of the feed in the feeding of farm animals.

Today about 3500 food and technological products are produced from corn. Corn can largely satisfy the needs of livestock, its share is almost 30\% of concentrated feed. With the advent of new directions in the development of biotechnology in the world, the significance of this culture will increase even more. The programs of biofuel production are gaining momentum, in connection with which a significant expansion of the sown area under the corn is foreseen.

In this article features of water-heat treatment of corn grain during preparation for processing are provided. Features of the use of hot and cold grain conditioning in the cereal industry are considered. In the course of this study, it was determined that the optimum water temperature for humidifying corn sugar is $60{ }^{\circ} \mathrm{C}$. Using a certain water temperature during humidification will enable to perform more efficiently the directed change of technological properties of grain, to ensure the high efficiency of its further processing. The results of research of the water absorption capacity of sugar corn grain are presented. As can be seen from the research carried out to improve the efficiency of the STI and optimize the processing technology, the grain lots are fractionated into more homogeneous flows of physical properties and treated separately.
\end{abstract}

Key words: grain processing, corn, water absorption, hydrothermal grain processing.

\section{Introduction}

Corn is a highly productive plant of tropical origin. Its homeland is Middle and South America, which explains the needs of the plant in warmth for its growth and development $[4,5,7]$. It is the most productive grain crop that is widely used as:

- raw materials in the food, pharmaceutical, chemical and other industries;

- high-energy feed suitable for feeding all types of animals and poultry;
- raw materials for the production of biofuels of the first and second generations;

- raw materials for biogas production.

The agrotechnological significance of this crop is also great, as it clears the soil from weeds and is a good precursor in the crop rotation. Due to the absorption of carbon dioxide and the release of oxygen, corn holds one of the first places among all cultivated plants and is even more effective than the forest of a similar area [6, 8]. Valuable properties of corn cause its stable high de 